\title{
Abstract: A Preoccupation with Perversion: the British Response to Refugee Claims on the Basis of Sexual Orientation 1989-2003
}

Britain's approach to refugee claims by lesbians and gay men has been notably hostile in comparison with other Western refugee receiving nations. For many years decision-makers in the UK refused to accept that those fleeing persecution on the basis of sexual orientation were even capable of being refugees under the terms of the Refugees Convention. Since accepting eligibility in 1999, UK decision-makers have repeatedly held that asylum seekers are under a duty to protect themselves by hiding their sexuality. They have also been extremely reluctant to hold that criminal sanctions for gay sex are themselves persecutory and have frequently failed to appreciate the relationship between violence against lesbians and gay men and the existence of criminal provisions.

This article suggests that there is a discernible national response in the Courts and Tribunals of Britain to sexual orientation based refugee claims. That response carries echoes of the 1956 Wolfenden Report, most notably its 'solution' to the 'problem' of homosexuality: privacy. 


\title{
A Preoccupation with Perversion: the British Response to Refugee Claims on the Basis of Sexual Orientation 1989-2003
}

\author{
Jenni Millbank*
}

For my part I am anxious to emphasise that the applicant makes this application as a homosexual male who seeks, or would seek, an adult male partner and whose homosexual practices would be conducted in private with that partner. I assume this in his favour. If there was any suggestion that $\mathrm{s}$ 377 discriminates in India against homosexual men who engage in homosexual practices with minors or in public then, in my view, entirely different considerations would arise. Needless to say, those would militate strongly against the applicant.

(J ain (1999) per Evans LJ (concurring judgment): 32)

Britain's approach to refugee claims by lesbians and gay men is notably hostile in comparison with other Western refugee receiving nations. For many years decisionmakers in the UK refused to accept that those fleeing persecution on the basis of sexual orientation were even capable of being refugees under the terms of the Refugees Convention. ${ }^{i}$ While receiving nations such as Germany, the USA, Canada, New Zealand and Australia accepted sexual orientation ${ }^{\mathrm{ii}}$ and gender identity as aspects of the particular social group category of the Refugees Convention in the late 1980s and early 1990s (Millbank, 1995; Walker, 2000) and the United Nations High Commissioner for Refugees (UNHCR) concurred in 1995 (UNHCR, 2001; note also the recent Council of Europe directive, 2003), the United Kingdom finally accepted eligibility only in 1999 after some strongly worded obiter was issued by the House of Lords in the gender and particular social group case of Shah and Islam (1999; see Symes, 2000; McGhee, 2001). Since the UK accepted that sexuality could formally qualify under the Convention ground, it has issued extremely restrictive decisions at Adjudicator, Tribunal and Court levels when compared with decisions of other countries such as Canada and Australia.iii Against this background, this article will focus upon distinctive features of the British response to lesbian and gay asylum seekers.

The restrictive view that British decision-makers have taken to refugee claims on the basis of sexual orientation is evidenced in a number of areas. For instance, UK decision-makers have repeatedly held that asylum seekers are under a duty to protect themselves by hiding their sexuality. (While this was also true to a somewhat lesser 
extent of Australian decisions, the High Court of Australia definitively rejected the 'discretion' approach in late 2003.) British decision-makers have also been extremely reluctant to hold that criminal sanctions for gay sex are themselves persecutory. Moreover they have frequently failed to discern any relationship between violence against lesbians and gay men and the criminalisation of same-sex sexual relations in the sending country.

This article suggests that there is a discernible national response to sexual orientation claims in the Courts and Tribunals of Britain. That response carries echoes of the 1956 Wolfenden Report, most notably its 'solution' to the 'problem' of homosexuality - privacy. In her analysis of parliamentary decriminalisation debates in Britain (and elsewhere) that followed from Wolfenden, Emma Henderson concludes that the most apparent theme of liberal discourse in these debates is how best to "disappear" homo-sex' rather than conceiving of privacy as a source of positive freedoms (1996:1030). In the case of Jain, quoted at the outset of this paper, a gay man presented to authorities in England and argued that he faced persecution in his home country because, among other things, gay sex is criminalized there. The response of the judge was to assure himself that the applicant was not 'really' a criminal by reference to an unstated standard, Britain's own criminal laws on gay sex - which lay a particular stress on the protection of minors and public order. While a concern with the protection of vulnerable youth and the delicate sensibilities of the public is not unique to the UK, these themes are pronounced in British gay and lesbian refugee claims. This is a particularly striking occurrence in the refugee setting because it is the lesbian or gay man who is the victim of state sanctioned violence, and yet decision makers respond by assessing the risk that they pose to the public. Wayne Morgan argues that greater attention must be paid to the 'violence done by the gaze of legal authority' in the context of international human rights law (Morgan, 2000: 212).

This article seeks to explore the violence of law in refugee decisions on sexual orientation over the past 15 years. The first section briefly explains some ways in which British decisions have been unresponsive to sexuality based refugee claims. I suggest that this reflects a cultural focus on 'the private' as the proper place of homosexuality and as the only response to the problem it poses to the polity, even when the state is an agent of persecution. The paper explores similarities between 
narratives of police persecution in Zimbabwe, one of the main countries of origin of lesbian and gay refugee claimants in the UK, and that which occurred in Britain prior to the decriminalisation of gay sex in 1967. Claims from another major sending country, Romania, also provides a fascinating counter-point to recent British legal developments. Prohibitions on public expression of homosexuality in countries such as Romania neatly reflect the 'economy of silence' around homosexuality (Moran, 1996) which found expression in the UK through avenues such as Clause 28 of the Local Government Act (1988). I argue that these commonalities, and the profound impact of the Wolfenden Report in creating the 'homosexual of law' (Moran, 1996) help to explain the distinctive and highly problematic response of the British to sexuality based refugee claims. iv All cases discussed below are from UK Courts and Tribunals unless otherwise indicated.

\section{The Context of Refugee Claims}

It is widely accepted that Refugees Convention persecution entails the 'sustained or systemic failure of state protection in relation to one or more of the core entitlements recognised by the international community' (Haines, 2003: 327): but which 'core' rights are recognised and how severely must they be breached before refugee protection is invoked? These questions may be answered differently in each receiving nation, as they implement their Convention obligations through domestic legislation and domestic determination procedures.

Refugee decision-making bodies often occupy an uneasy status, embodying both public and private status and indeterminate legal norms. In most countries refugee decision-making is undertaken by fairly low level bureaucrats at first instance; in the UK and Australia these public servants in fact work within the Ministry for Immigration acting as the Minister's delegate (Crock, 1998; Lambert, 1995; Thomas, 2003). The process often remains bureaucratic upon appeal through the common use of low formality tribunals which may be staffed by a high proportion of non-legal personnel (Thomas, 2003). In Britain the initial decision is made by a civil servant representing the Secretary of State for the Home Department ('SSHD'), a full rehearing of the claims may then be made before an Adjudicator (who can either affirm or overturn the decision, and also has the power to certify that the claim is 
unmerited such that further appeal is not open). Appeals from Adjudicator's decisions (unless certified) are then made to a three person Immigration Appeals Tribunal (the IAT, which may affirm or overturn the decision or remit it to another Adjudicator). In Britain, as in many other Western refugee receiving nations, refugee claims are largely, and increasingly, unreviewable in the courts (Kneebone, 2002; Mathew, 2002). Judicial review of IAT decisions are on very narrow grounds and if successful result in decisions being remitted to the Tribunal (although on occasion points of law may be appealed directly from the IAT to the Court of Appeal). ${ }^{v}$

Sexuality claims in all areas of law have long provoked indeterminacy in relation to categories used to contain and exclude them, and their relationship as 'others' to the 'us' of the nation state. Carl Stychin has linked sexuality with anxiety about the boundaries of the nation state, 'both migration and homosexuality have an unfixity and an excessiveness that needs to be contained to prevent invasion' (2000: 610). In the UK prior to 1999, sexuality cases were excluded from the 'particular social group' category and many cases were therefore determined on the discretionary basis of 'exceptional leave' (Tuitt, 1996: 36). Since 1999 British decision-makers have continued to show a reluctance to make findings on Refugees Convention grounds.

Provisions in the Human Rights Act (1998) rendering it unlawful for a public authority to act in a way incompatible with a right arising under European Convention for Human Rights (ECHR) became operative in October 2000 (Blake, 2001). Since that time the bulk of lesbian and gay refugee decisions in Britain have been focused not upon refugee protection but upon the claims to non-refoulment due to potential breach of ECHR provisions such as Article 8 (privacy and family life). The hard' rights of refugee law are set apart from, and above, the 'soft' rights of national and international human rights. Article 3 (torture or inhuman and degrading treatment) has been placed as a stepping stone in this hierarchy between real harm and mere discrimination. Many of the lesbian and gay claims in Britain rested upon Art 8 as the harms experienced by them were constantly equated with the 'unpleasantness' of discrimination and not the real harm of persecution. Even when included in the ambit of state protection, lesbians and gay men have still been defined as other, as not-refugee, and their presence has served to invoke a desire to reinscribe, rather than remove, borders and boundaries. 
It is vital to note that the ECHR avenue of non-refoulment, open from 2000-2002 when many of the cases under discussion in this paper were decided - is now virtually closed. In 2002 the UK Court of Appeal rejected Article 8 ECHR considerations as the basis to prevent refoulment except in the case of the grossest violations, effectively limiting human rights considerations to very serious breaches of Art 3. This approach was upheld on appeal to the House of Lords in 2004. (Ullah and Do (2002); Ullah (2004). The standard of Art 3 is one that lesbian and gay claimants, even those who have been raped and bashed by police (Kizza (2002)), or faced criminal penalties for gay sex (Applicant A in Z, A and M (2002)), have been held not to meet. It is therefore highly likely that the number and proportion of successful claims on the basis of sexual orientation in Britain has fallen since 2003.

\section{Failure to Surface}

To claim 'core' human rights for lesbians and gay men is paradoxical given the marginality of sexual minorities in human rights jurisprudence to date. Sexual orientation has only very recently been acknowledged as a valid locus of human rights in international law (Morgan, 2000) has been of limited scope there (Morgan, 2000; Stychin, 1998: 115-144,) and is typically still far from widely accepted as the basis for equality claims in many refugee receiving nations. Western 'civilized' nations would like to think of themselves as modern on these points and the sending nations implicitly as undeveloped or unenlightened (Sealeunu (1997): para 14; S (2003): para 22). Yet decision-makers exert themselves in numerous ways to contain nonconforming sexualities within acceptable 'moral' bounds as part of this civilising process and judge harshly applicants who have come to the attention of authorities because of their presence in public spaces such as cruising locales. vi Decisions are disciplinary in that they demarcate the bounds of tolerance (Morgan, Otto and Walker, 1995) and centre on the proper place of sexual subjects informed by shifting conceptions of the public/ private spheres.

The UK's initial refusal to accept that sexual orientation as an eligible status under the social group category was premised on the basis that sexuality was an association 
of a private and purely voluntary nature (McGhee, 2001). In an early decision, the Secretary of State argued that:

Homosexuals...are a group but their only common characteristic is a sexual preference which, if it is revealed at all, is normally only revealed in private. A group cannot be a social group if its only common characteristic is so concealed. (Quoted on review R v Secretary of State ex parte Binbasi (1989). See also Gochin (1991); discussed in McGhee, 2000)

While this analysis was ultimately rejected in Shah and Islam (1999), the fundaments of choice and concealment have continued to influence decisions on sexuality to date.

The doctrine of liberal tolerance dictates that one should live and let live, however this tolerance is distinctly premised on the understanding that the tolerated others will quietly confine themselves to a consensual private realm where they can remain unmolested by the state and un-bothersome to their heterosexual neighbours (Morgan, 2000; Stychin, 1995: 148). Yet claimants are only eligible for refugee status if they have somehow breached this implicit injunction and come to, or are at risk of coming to, the attention of authorities in their home state. The heteronormative injunction to be silent about non-heterosexuality (Mason, 2002: 78-79) must be breached for a claim to be articulated. Under the norms of the receiving nation, 'good' quiet unnoticeable gay people may be constructed as too good to need protection (Millbank, 2003; see eg Dumitru (2000)). Silence about one's sexuality has also been taken to disentitle the applicant from raising the claim at a later point either because it reflects poorly on credibility or because the claim is out of time (see eg Arku (1997); Khan (1999); Bell (2000); S (2003)).

Decision-makers themselves may reinforce the expectation of silence around sexuality. Although apparent in many Australian decisions (Dauvergne and Millbank, 2003), a requirement or expectation of 'discretion' is particularly prevalent in the UK. In Binbasi (1989), the original decision-maker held that the risk of prosecution of a gay man in Turkish Cyprus could be avoided by 'self restraint', which in that case was intended to encompass complete sexual abstinence. Although this reasoning was approved in one recent Tribunal decision regarding a gay man from Brunei - who had been sexually active only since leaving his home state (Boyd (2000)) - most UK decision-makers require or assume different degrees of hiding one's sexuality rather than absolute suppression. So for example, 
In Yemen the Appellant could live quietly and privately in a homosexual relationship without fear of persecution by the authorities'. (Adjudicator quoted on appeal to the IAT in Saeed (2002): para 48)

or

He has not said that he wishes to act in any particular way or in a way which might put him at risk. It is likely that he appreciates what is and is not acceptable in Iran'. (Musavi (2002): para 12)

Decision-makers seem oblivious to the connection between social and state repression and applicant's 'discretion'. Derek McGhee argues that, This production of 'invisible' homosexuality perpetuates the continual social eradication of the expression, public visibility, and even the practice of homosexuality in the countries concerned' (McGhee, 2001: 25).

Reversing the Convention aim that the receiving state provides a surrogate for protection from the home state, the discretion decisions place the onus of protection upon the applicant: it is he or she who must avoid the harm (Dauvergne and Millbank, 2003; Germov and Motta, 2003: 327). Patricia Tuitt notes that the discretion standard 'may result in the host state indirectly colluding with the persecutory state in limiting the extent to which the refugee is free to assert the rights and freedoms about which his claim to asylum may well have been prompted' (Tuitt, 1996: 93).

Discretion reasoning has been applied even in cases where the applicant has stated that they do not wish to, or intend to, be discreet if returned to their home country. In a 1999 claim brought by a gay man from India, the Court of Appeal accepted that the Tribunal's findings were 'consistent with the Appellant being handed over to the police if he lives openly as a homosexual and being at risk of 'brutality' in their hands' but did not disturb the Tribunal decision to deny protection. Despite the claimant's own evidence that he wanted to live openly (he was 'unable to live what is to him a 'normal lifestyle', by which he means he will be unable to live openly in a homosexual relationship' (Jain (1999): para 9), the Tribunal determined that he would be 'discreet' and therefore safe from harm. Through the norm of invisibility decisionmakers have continued to employ the violence of the law to force applicants back into their home country closets. 
In contrast to other refugee receiving countries such as Canada, the UK has demonstrated a marked reluctance to accept that lesbian and gay asylum seekers are entitled to voluntarily disclose their sexuality in their country of origin. Even making such a demand entails presenting to the decision-maker as a 'bad' or unreasonably militant gay person. It is significant that in some cases the claim to self-expression is not even conceptualised as a right-claim, as in the case below where the fear of a gay man from Pakistan is trivialised and privatised into a 'right to go clubbing'. The adjudicator found that:

The Appellant's demeanour in court supported his claim to be a homosexual desirous of living openly as a homosexual but only in the gay community. ... His fear is of persecution should he return to Pakistan and behave there as an open and outed homosexual and in a promiscuous manner. ... My task is to consider the likelihood of the Appellant facing persecution should he return to Pakistan and behave there as he behaved before he left Pakistan or behave there as he has currently been organising his social activities in the United Kingdom. I have to accept that there is probably not an open gay community in Pakistan as there is in this country. There will not be in Pakistan gay clubs or gay pubs. The second alternative scenario can probably therefore be discounted because the circumstances in which the Appellant moves socially in the United Kingdom do not apply in Pakistan. It is of course not a Convention reason that an asylum seeker returning to his own country is unable to enjoy there the peripheral benefits of westernised and so called liberalised behaviour. ... the Appellant has failed demonstrate that he would face problems if he were to return to Pakistan and resume his former lifestyle there. To attract problems he would have to flaunt his homosexuality. (Quoted on review, T (2000): paras11-12)

The decision, undisturbed by the Court (and later by the Court of Appeal) clearly rests upon assumptions discussed above about the ability of the applicant, no matter his own evidence to the contrary, to be discreet'. It also demonstrates a dogged determination not to conceptualise the life experience (designated 'social activities') of a gay man in terms of human rights concepts such as self expression or freedom of association. The liberalised West is contrasted with the repressive East, but it is also implicit that the West has gone too far and very real repressions in this instance (including 100 lashes or imprisonment of between 2 years and life under s 377 of the Pakistan Penal Code and 100 lashes or death by stoning under Shari'a law) are elided by reducing a gay sexual identity to the opportunity to go out clubbing. 
A norm of invisibility has also lead to UK decision-makers refusing to accept that persecution is likely because country information on persecution is so scant. In numerous cases this involves the decision-maker effectively ignoring the claimant's specific evidence of abuse (even where they accept the truth of that evidence) in favour of the silence on human rights abuses on sexuality generally. The general (objective) silence is privileged above the specific (subjective) experience of the applicant. So for example in a Tribunal decision in 2003 a lesbian from Uganda gave evidence that she had been banished for lesbianism from her area by a local council and had been sexually assaulted by police when she campaigned against President Museveni (who has incited hatred against lesbians and gay men in numerous public statements: see Human Rights Watch, 2003: 2, 50, 51, 160). Unusually, expert evidence of homophobia in Uganda was available to the Tribunal. The expert attested to a homophobic and masculinist culture and suggested that it raised a likelihood of persecution for a woman in the applicant's situation. The Tribunal responded by calling upon the silence:

We suppose that depends on what one means by persecuted. If it was intended to indicate that she would be persecuted to the level required by the refugee Convention, then we are wholly unable to accept on the material that we have seen that relates to the objective situation in Uganda. Lesbianism appears to be exceedingly rare, or at least there is precious little material which deals with it in relation to Uganda. When we say lesbianism is rare, we do not mean that there are not a number of lesbians, what we mean is that problems relating to lesbians have singularly failed to surface. That of course, may only mean that they are forced to keep their proclivities under cover. But there is no real evidence to support a suggestion that lesbians as such are persecuted to the level required to enable the Convention to be brought into play. (Kizza (2002): para 5)

Lesbians 'as such' are not persecuted, because no one knows they exist. The 'failure to surface' of lesbians generally in Uganda is here used to eradicate the experience of this lesbian claimant, rather than, for instance, to support her claim of fear of persecution by reference to the degree of disapprobation that would generate such pervasive silence, or to the heightened risk of her position as an exposed lesbian with no means of support from other lesbians or organisations. Similarly, in another lesbian case the SSHD delegate doubted the applicant's claims of failure of police assistance in Kenya on the basis that it was not normally an issue taken into the public domain. There was no evidence of persecution on account of sexual orientation' (Maingi (2001): 7). Lesbians being unknown and never going to the 
police for help becomes evidence that lesbians are not persecuted or refused protection. The expectation of silence and conformity is so strong that decisionmakers may privilege an imagined (discreet) lesbian or gay life over the applicant's past experience in addition to valuing it over their testimony about their current and future conduct.

\section{Privacy, naturally}

It is argued that this norm of invisibility, although not unique to English culture, is closely connected to the influence of the Wolfenden Committee's 'solution' to the 'problem' of homosexuality. Indeed, Emma Henderson believes that the liberal political arguments for decriminalisation were premised on the idea that invisibility would become a form of freedom' (1996: 1030).

In its 1956 report the Committee conceived of sexual behaviour as something that, while it may be regarded as 'sinful, morally wrong, or objectionable for reasons of conscience, or of religious or cultural tradition', was essentially outside of the 'proper sphere' of the law's concern (Wolfenden Report, 1956: 10, 21).

We do not think that it is proper for the law to concern itself with what a man does in private unless it can be shown to be so contrary to the public good that the law ought to intervene in its function as the guardian of that public good. (Wolfenden Report, 1956: 21)

Criminal law was justified in proscribing conduct where it impacted upon public space or posed a threat to public morals, but when it was consensual, adult and in private then such sex was best left alone. It was, still, however unquestionably a 'problem' as evidenced by the repeated use of such terminology in Chapter headings ('Our approach to the problem', The prevalence of the problem') and the Committee's consideration of deterrence and treatment as appropriate responses to homosexuality (Wolfenden Report, 1956: Chapter 7). The 'solution' was therefore in a sense to ignore 'the problem' when one was able to, while preserving a sense of law as instrumental in containing and controlling public order by defining this 'problem' as not naturally part of its ambit. Proper place (Cooper, 2001) was assumed, naturalised and static. Gay men were out of place in the public, and conceptualised as inherently transgressive in that sphere. Henderson notes that, 
Rather than being related to autonomy and freedom to make choices, this view of privacy is all about maintaining the appearance of conformity with dominant norms. (1996: 1035).

In the Wolfenden schema, then, gay men by being 'discreet' and staying out of harm's way are acting appropriately. In this way the conduct of the state in pressuring or forcing such discretion becomes irrelevant.

Although criminal law reform did not take place in England until 1967 the reforms largely mirrored those recommended by the Wolfenden Committee (Scotland followed in 1980 and Northern Ireland in 1982, after the Dudgeon decision of the European Court of Human Rights in 1981). But anxiety about the spread of homosexuality and the protection of public space was far more evident in the reformed legislation than in the Committee Report. The offences of 'buggery' (Sexual Offences Act 1956: s 12) and 'gross indecency' (Sexual Offences Act 1956: s 13, including procuring such acts) remained on the books as offences, but the sections were inapplicable if the act took place in private: privacy in effect formed a complete defence to acts that were still characterised as wrongful. The 1967 reforms defined privacy such that it could not include any situation in which more than two people were present and also introduced the new offence of procuring others to commit homosexual acts (Sexual Offences Act 1967: s1, s4. See generally Weeks, 1977: 168182). Many commentators have noted that police presence on public beats and cruising locales such as public toilets and the use of police entrapment at such venues intensified in the years following the reforms. Arrests and convictions of men engaged in same-sex sexual activity actually increased after the reforms (see eg Weeks, 1977: 11; Jeffery-Poulter, 1991). Control, surveillance and regulation of the public sphere were enhanced. Jeffrey Weeks argues that, by ceasing to be the guardian of private morality, the law would more effectively become the protector of public decency and order' (1989: 243). Although the age of consent was lowered from 21 to 18 in 1994 and then to 16 in 2000 (Waites, 2001; 2003) the public gay-specific provisions of the 1967 Act were not removed until 2003 (via the Sexual Offences Act 2003; see also ADT v UK (2000) regarding the impact of the ECHR).

The private is that which is not public, and public-ness is defined as much by nonconformity to public norms as any incursion into public space. David Bell wrote in 
1995 of the tight boundaries of tolerance and narrow definition of the private inscribed by the 1967 reforms:

In Britain, sex between two men outside the confines of the bedroom is still often intolerable. Sex in the bedroom is intolerable if it involves anything but the most conventional 'straight', most 'vanilla' definition of what constitutes 'sex'. So is making a video, or taking photographs of sexual activities (with the Obscene Publications Squad ever watchful). So is having sex in anything bigger than a twosome (by the Wolfenden Act's definition, sex with three or more men present, let alone participating, is 'public'). So is winking at a man in the street (this can be classified as procurement or soliciting). So is exhibiting a painting with a 'gay' theme, or even trying to publish an academic book on homosexuality (thanks to Section 28 of the Local Government Act ...). So is owning a vibrator or even a leather jacket (which can become, in the right setting, 'obscene material'). And so, of course, is being caught in the public toilets or in a cruising area. (Bell, 1995: 309)

The more non-conforming one is, the more public one is: this conception of privacy also emerged in the refugee decisions. In a 1998 UK case, a gay man from Bulgaria had been twice arrested for 'immoral behaviour' when police, notified by neighbours, had raided his apartment when his partner was staying. Although gay sex in Bulgaria was legal by that stage, the post-decriminalisation Criminal Code provided that:

Whoever engages in homosexual acts in public or in a scandalous manner or in way so as to entice others to perversity will be punished with a prison sentence of up to two years. (Art 157(3), cited in Apostolov (1998))

Despite the fact that the applicant had been in his own home on both occasions, the Tribunal had no difficulty in concluding that this fell 'well short of persecution' as he had been arrested 'only twice', 'detained for a relatively short period of time overnight on both occasions' and not charged. The Tribunal did not question that such conduct fell within the ambit of the Code or whether the Code had been applied in a discriminatory manner, Indeed, the Tribunal found that the police were obliged to investigate the complaints; the intervention of police was itself seen as proof of the non-private nature of the conduct. As a member of the House of Commons stated in the 1958 decimalisation debates, Intercourse in private is not found out. If it is found out, it cannot have been in private' (quoted in Henderson, 1996: 1035). The Tribunal did not even question whether having sex in one's own home came within the terms of the criminal code: the public in this sense was normative not spatial. (See also use of the pre-2002 Romanian prohibition on public scandal against gay men and lesbians who disturb neighbours or 'make too much noise': Human Rights Watch, 
1998: 38-47). While more extreme than an English domestic response would be, the Bulgarian state reaction was not sufficiently out of step with English norms to be adjudged persecutory, or even discriminatory.

In post-Wolfenden Britain, continuing surveillance and policing of public morals and public space was evidenced the successful prosecution in the 1970s of the owners and editors of a newspaper for 'conspiracy to pervert public morals' when it included male-male personal advertisements ( $\mathrm{R} v$ Knuller (1972)). In that prosecution, Count 1 of the charge was phrased as a conspiracy:

to induce readers to meet those persons inserting such advertisements for the purposes of sexual practices taking place between male persons and to encourage readers to indulge in such practices, with intent thereby to debaunch and corrupt the morals as well of youth as of divers other liege subjects of Our Lady the Queen. (Quoted in R v Knuller (1972))

Knuller was appealed up to the House of Lords (in Knuller v Director of Public Prosecutions (1973)), and at all levels the charge of conspiracy to pervert public morals was upheld. (See also the privately initiated criminal prosecution of a gay paper for blasphemous libel: R v Lemon (1979)). The decision rests upon the premise that gay sex while legal, or perhaps more correctly, not illegal in certain circumstances, is still of such dubious morality that the criminal law could prohibit its spread if not its actual commission. In Lord Reid's words,

I find nothing in the [1967] Act to indicate that Parliament thought or intended to lay down that indulgence in these practices is not corrupting, if people choose to corrupt themselves in this way that is their affair and the law will not interfere. But no licence is given to others to encourage the practice.' (at 457)

In the 1980s gay men who kissed at a bus stop in the early hours of the morning were prosecuted for 'insulting behaviour likely to cause a breach of the peace' (Masterson v Holden (1986)). Prosecutions in the 1990s such as those concerning consensual sadomasochistic gay sex in the Spanner case ( $\mathrm{v} v$ Brown (1993)) and consensual gay group sex (R v T (1999)) highlight the ongoing applicability of the post-Wolfenden legal provisions. Police willingness to keep them from falling into dead-letter status was put into effect through their investment of time, money and personnel in surveillance, investigations and prosecutions for non-conforming sex. In these cases, in contrast to those that concern sex in public toilets (of which there were manyvii) the 
'public' aspect of gay sex is more clearly normative than spatial. As David Bell argues, these kinds of gay sex are seen to be harm to the 'public good' because of the extent of their non-conformity. As a consequence a nebulous, vulnerable 'public' is identified by law as the victim of these 'crimes' (Bell, 1995).

There is an anxious re-inscription of boundaries around the public (public sphere, public morals, public interest?) by the judiciary in their published reasons as they rationalise the role of criminal sanctions. In the Wolfenden formulation, the function of the criminal law

is to preserve public order and decency, to protect the citizen from what is offensive or injurious, and to provide sufficient safeguards against exploitation and corruption of others, particularly those who are specially vulnerable because they are young, weak in body or mind, inexperienced, or in a state of special physical official or economic dependence. (Wolfenden Report, 1956: 9-10)

Perhaps it is unsurprising that the protection of 'youth', or more accurately young men (in Knuller (1972), they were repeatedly identified at Court of Appeal level as 'schoolboys'), features heavily in these cases as in other legal texts. Les Moran (1996) and Carl Stychin (1995) have analysed the House of Lords decision in Brown (1993) in detail and documented the majority judges' thematic concerns of corruption (of youth, of the male body and of sexual morals), proselytization, addiction and infection (Moran, 1996: 180-191; Stychin, 1995) in finding that 'society is entitled and bound to protect itself' against the conduct of the accused (Stychin, 1995: 119; quoting Lord Templeman). Interestingly, in Masterson (1986), when two gay men expressed their sexuality in the most 'vanilla', non-predatory, non-perverse manner possible by having a kiss and a cuddle in a setting where there could be no question of the corruption of male youth it was the vulnerability of 'young women' that was the focus of the judiciary as two passers-by were taken to stand in for the general victimised public. No matter what, there must be a victim, and in the almost absurdly victimless prosecutions of Knuller (1972) and Brown (1993) there was no doubt in the judicial mind that the victim was the public.

The shadow of the seductive and degenerate homosexual (Stychin, 1995: 133; Henderson, 1996: 1041-1043) also appears prominently in the asylum cases, despite the fact that he is presenting as the victim himself. Even quite severe criminal proscriptions were characterised as non-persecutory by reference to the protection of 
youth and the public morals. This was made explicit in a recent claim from a Bulgarian gay man in which the Adjudicator stressed that gay sex was legal and construed the Bulgarian Code in the following manner:

Whilst art 157 does contain provisions... that proscribe performance of sexual acts with members of the same sex, these proscriptions are confined to provisions designed to ensure the protection of persons in a position of dependency or supervision or who are deprived of the possibility of selfdefence or who are minors.. However, whilst this clause has been criticised for evidencing an anti-homosexual bias, it draws short of proscribing homosexual acts as such and sets out instead limits to types of homosexual conduct that are within the law. (Adjudicator quoted in review, Lepoev (2000): para 15-16)

While specific provisions of the Code relate to the protection of minors, those in positions of dependency and those unable to defend themselves Code itself plainly goes further that this by additionally proscribing scandal and enticing to 'perversity' in the most general terms. The Bulgarian Code and the refugee decision in question both appear to read any expression of homosexuality and enticement into perversity as fairly much the same thing, and exemplify an extreme heteronormative understanding of gay men's sexuality as a form of threatening übermasculinity; predatory, voraciously and indiscriminately sexual, uncontrolled and uncontained (Stychin, 1995: 117-139; Moran, 1996: 188).

This understanding is mirrored in widely used terminology in the refugee cases, for instance the applicant's claim is frequently characterised as a 'wish to indulge in homosexual activity/acts' (see eg Binasbi (1989); Vraciu (1995); Jain (1999); T (2000); Z (2002)). In addition to signifying an identity/ act split that is common to right wing discourse on sexuality (Henderson, 1996; Herman, 1997: 69-91), the repeated use of 'indulge' rather than, say 'engage', or a characterisation of the gay applicant as someone who wants to have a relationship in addition to having sex, brings with it a clear sense of carnality, appetite, lack of self control, and the corollary of self indulgence (see also Z, A and M (2002), where the IAT uses the expression 'carnal' and also 'male paramour'). The terminology of 'indulgence' is also a marked feature of the Wolfenden Report and the judgments discussed earlier such as Knuller (1972) and Brown (1993). (Interestingly, it also features in one of the dissenting judgments, but not the majority, in the ECHR decision on criminalisation of gay sex, Dudgeon (1981): paras 3, 4, 7, 13, per Walsh J). This construction of gay male 
sexuality goes some way to explaining the anomalous reluctance of British decisionmakers to construe criminal penalties against gay sex as potentially persecutory.

\section{Sexual Misconduct}

Homosexuality, as with many other forms of sexual misconduct, is a criminal offence in Pakistan punishable by, in this case, up to life imprisonment, and is also a religious offence which could attract a death sentence by stoning.

(T (2000): para 2 per Tuckey LJ )

Criminalisation of sex is a very obvious and clearly state sanctioned form of harm against gay people. In 2002 the Office of the United Nations High Commissioner for Refugees indicated that '[w] here homosexuality is illegal in a particular society, the imposition of severe criminal penalties for homosexual conduct could amount to persecution' (UNHCR, 2002:17). Yet decision-makers in Britain have demonstrated a marked reluctance to view criminalisation of gay sex per se as persecutory, and have been far slower than jurisdictions such as Canada and Australiaviii (and the latter is no paragon: see Dauvergne and Millbank, 2003) to appreciate a connection between criminalisation, failure of police protection and persecution. This is particularly odd given that decriminalisation of gay sex in the UK was many years in advance of jurisdictions such as Canada, Australia and the US (where although many states abolished criminal provisions, it was only accepted at a federal level that criminalisation was unconstitutional in 2003).

In 1989 the High Court of J ustice was able to blithely remark that 'apart from risking prosecution, he would not be victimised in any other way' (Binbasi (1989)). Early UK decisions treated even laws specifically targeted at, or enforced only upon, homosexuals as laws of general application (see eg a 1995 decision of the High Court of J ustice considering penalties of imprisonment of 1-5 years for gay sex in Romania a 'normal policy of enforcement of the criminal law' and not persecution: Vraciu (1995): para 11; discussed in McGhee, 2000: 29-30). In the 1999 Court of Appeal decision Jain, the UK accepted that criminal laws if enforced could be persecutory, but appears to have dramatically resiled from this position in a number of recent cases. 
Recently, decision-makers have held that criminal punishments for gay sex are not persecutory if they are not 'disproportionate'. In a 2002 case, an Immigration Adjudicator held that the Appellant would not face persecution if he were returned to the Yemen by the Yemeni authorities only prosecution and any punishment [100 lashes or 1 year in prison], within the context of the Yemeni culture would not be harsh and unconscionable' (Saeed, Adjudicator's decision (2002). The 'context' in question may be one in which heterosexual adulterers face criminal sanctions such that 'the authorities punish offenders regardless of sex religion or nationality' (Saeed (2002), quoting the findings of the Adjudicator). ix In another 2002 case the Tribunal denied the application of an Iranian man who had been caught in a relationship with another young man while at school. The Adjudicator accepted evidence that he had been handed over to the authorities, beaten and seriously ill-treated by them, and then imprisoned for six months. The findings of the Adjudicator, undisturbed by the Tribunal were that, There was nothing to suggest that the ill-treatment he suffered was state sanctioned. His sentence of six months for homosexuality and sodomy was not disproportionate and relatively lenient' (Musavi (2002): para 5). Proportionate and lenient are provocative terms in this finding; they own that this judgment is a relative one, and thus call forth the unspoken comparator. Not disproportionate and relatively lenient compared to what? Some other kind of penalty imposed on heterosexual teenagers engaged in their first relationship? To the maximum penalty against gay sex in Iran (death by stoning)? Criminal penalties against gay sex in Britain prior to decriminalisation? Moreover, the applicant can only be taken to have gotten off lightly if it is first accepted that he is indeed acting unlawfully.

Although the 1999 Court of Appeal decision Jain held that mere criminalisation did not entail persecution, it did plainly state that enforcement or risk of prosecution could amount to persecution.

As it seems to me there is now a broad international consensus that everyone has a right of respect for his private life. A person's private life includes his sexual life, which thus deserves respect...the position has now been reached that criminalisation of homosexual activity between consenting adults in private is not regarded by the international community at large as acceptable. If a person wishes to engage in such activity and lives in a State which enforces a criminal law prohibiting such activity, he may be able to bring himself within the definition of a refugee. (Jain (1999): para 22) 
Yet in the 2001 case of Ashley and 2002 case of Saeed, the UK Tribunal and an Adjudicator held respectively that Jain supported their conclusions that prosecution was not persecution. While the Tribunal in Saeed pointed out that this was completely incorrect, the vast majority of cases at all lower levels have simply ignored Jain, holding that prison terms of 40 days (Ashley (2001)), 1 year (S (2003)) and up to ten years (Mbavsai (2001)) if imposed would not amount to either Convention persecution or to inhuman and degrading treatment under Art 3 of the ECHR.

Moreover, several of the above cases finding that prosecution was not persecution have been subject to judicial review, where these findings were either not dealt with or were approved in obiter (see Z, A and M (2002); S (2003)). So, for example, the High Court of J ustice said of a one year prison term 'without being taken to approve of any form of penal sanction for such behaviour or conduct, it falls short of that which engages Art 3' (S (2003): para 20). It is possible that this approach has been permitted to stand simply because so few judicial decisions have centred on the substantive issues or on Refugees Convention protection (prior to 2003 often examining ECHR issues in preference) such that a full and detailed appraisal of the question has not occurred despite the sizable volume of cases. Yet it is so plainly at odds with international human rights law that it deserves further scrutiny. This is all the more striking for the fact that a complaint against UK criminalisation of gay sex, Dudgeon, became the first successful claim by a gay applicant under the ECHR, and marks the real beginning of international human rights jurisprudence on sexual orientation.

Dudgeon (1981) concerned criminal prohibitions on gay sex that had largely been repealed in England in 1967, but left in place in Northern Ireland. The majority of the ECHR held that the right to privacy covered same-sex sexual relations and that the criminal sanctions in question breached this right (This decision then was followed by a very similar claim regarding Ireland: Norris (1991)). Given the fact that an identical statute had been amended following Wolfenden, and that both the Wolfenden Report and the Article of the European Convention in question centred the organising principle of 'privacy', it is unsurprising that the Wolfenden Report was highly influential upon the majority judgment in Dudgeon. The Court quoted and approved Wolfenden on restricting the criminal law to that necessary to protect 
public order and decency and provide safeguards against the exploitation and corruption of others, particularly those vulnerable because of youth etc (Dudgeon (1981): para 49, 62). The majority of the ECHR held that the law in question had gone beyond what was necessary to achieve these aims, but the minority judges argued that criminalisation was necessary, just, and proportional by reference to exactly the same factors. Wayne Morgan argues that far from disrupting the 'power of heterosex' both the majority and minority views 'validate the hierarchy which privileges heterosex' (Morgan, 2000: 219) - and they do so through affirming the Wolfenden implementation of that hierarchy.

In dissent, J udge Zekia held that decriminalisation would lead to 'public ... turmoil' (Dudgeon (1981): para 2) as the majority of citizens were united in their condemnation of 'unnatural immoral practices' (Dudgeon (1981): para 3). Zekia held that complete criminalisation of gay sex was necessary to protect public morals and preserve the public peace (Dudgeon (1981): paras 3, 5). In a partial dissent, Judge Walsh quoted the Wolfenden formulation to contest it thus:

experience has shown that exploitation and corruption of others is not confined to persons who are young, weak in body or mind or inexperienced or in a state of physical, moral or economic dependence. (Dudgeon (1981): para 12)

Walsh also veered far from Wolfenden in arguing that adults who were not 'innate' or 'incurable' faced the threat of seduction and corruption by homosexuals (Dudgeon (1981): paras 13-15). The other dissident, Judge Matscher, by contrast, explicitly identified the risk to the public as the contagion/ conversion specifically of youth. He was prepared to assume that when the police had arrested and questioned $\mathrm{Mr}$ Dudgeon it was 'probably' to investigate whether he had sex with minors: 'Indeed it is well known that this is a widespread tendency in homosexual circles'(Dudgeon (1981)).

In his analysis of J udge Walsh's dissenting judgment Leslie Moran has argued:

The connection between homosexual and human rights is not exhausted in securing a position for rights. Another intelligibility of 'homosexual' is also imaginable and always already installed in the conjunction of homosexual and human rights... Here homosexual' is not so much the subject of human rights but a possible victim for human rights and thereby the limits of human rights. (Moran, 1996: 179) 
Moran's argument is borne out clearly in the refugee decisions on sexuality. The gay man presents as a victim of the law, persecuted for expressing his sexual self. But he is quickly transformed into a predator, against whom the law must marshal its full strength to protect 'the public' especially the young and vulnerable. One of the few refugee cases to engage with international human rights jurisprudence on sexual orientation, the case of M (see applicant M in Z, A and M (2002)) demonstrates this. In that case, the Tribunal unusually relied upon the European Court of Human Rights decision in Modinos (1993) (which had held that criminal statutes even when rarely enforced, or unenforced are nonetheless in breach of human rights because of their effect on the individual) to find that unenforced [sic] criminal laws in Zimbabwe would lead to a breach of the applicant's ECHR Art 8 rights if he were refouled. The Court of Appeal then overturned the Tribunal decision which it declared to be an inappropriately broad reading of Modinos (1993) and of Art 8 rights. In doing so it revealed an implicit preference for the dissenting views in Dudgeon (1982) - a vision of the predatory homosexual that was already installed.

The Court of Appeal examined Modinos (1993) in some detail, although it principally relied on reading down the applicability of that case to the 'factual matrix' of Turkish Cyprus. The Court of Appeal in 2002 appeared to regret that the Cypriot government back in 1993 had not argued the case for criminalisation before the European Court more forcefully; indeed it suggested that had the Cypriot government argued the Art 8(2) justification on 'public health and morals' grounds, Modinos (1993) may not have been decided as it was. The Court of Appeal referred to a domestic decision of the Supreme Court of Cyprus some years earlier, Costa, which had upheld the constitutional legality of the sodomy laws in a case involving a 19 year old man who had been charged after being caught engaged in gay sex in a tent while in the military. While the European Court in Modinos had construed this as evidence that the Cypriot legal system was committed to on-going rights violations, the Court of Appeal appeared rather supportive than otherwise of the sodomy statue:

The Strasbourg Court did not decide whether the very same law might have been justified if, for example, it was used to prosecute non-private homosexuality (such as was the case in Costa) or homosexual activity with a young person requiring special protection (arguably the 19 year old in that case). (Z, A and M (2002): para 28) 
As the Court of Appeal did not explain its view further, analysis of this remark must rest on a considerable amount of inference. But it is striking that in 2002 an English Court was prepared to automatically equate public morals with the protection of young men ('arguably' a 19 year old man, over the age of consent in England by that time but still characterised as in need of 'special protection') from the threat of consensual gay sex. It is also reflects the unquestioning acceptance of the rightful prosecution of gay sex or sexual expression if it is conceptualised as in any sense public. The equation is made as if so obvious that it does not bear explanation. Gay sexuality is to be tolerated as lawful only in tightly circumscribed of privacy: a tent is public, public (gay) sex is inherently wrong, a criminal penalty of up to five years is therefore a legitimate punishment and not a human rights breach.

Criminal statutes in Eastern European states such as those in Romania until 2002 that 'set limits' on homosexual conduct by proscribing 'public scandal' are particularly interesting in the British context. The UK had released over two dozen decisions on Romania, the highest number by far from any country of origin. Unlike the situation in many other sending countries, human rights abuses in Romania were very well documented by the late 1990s as much persecution was judicially sanctioned (Human Rights Watch, 1998) and non-government organisations such as Human Rights Watch, the International Lesbian and Gay Association (ILGA) Europe Branch, and the International Gay and Lesbian Human Rights Commission (IGLHRC) conducted extensive fact-finding through the 1990s. Such documentation flew in the face of government claims of liberalisation' and attempts to posit all such abuses as belonging to the Communist era. In fact the so called 'decriminalisation' in Romania in 1996 involved replacing a complete prohibition of same-sex sexual relations with a clause that contained the same penalty for homosexual acts but limited it to situations where they were 'committed in public or if causing public scandal' (Art 200, Clause 1). The 1996 amendments broadened the applicability of incitement provisions, making it an offence to 'entice or seduce a person to practise same-sex acts, as well as to form propaganda associations, or to engage in other forms of proselytising with the same aim' (Art 200, Clause 5). The 1996 public scandal provisions were widely condemned by human rights organisations as Amnesty International and Human Rights Watch (see Human Rights Watch, 1998: 3, 38) as extremely discriminatory. The provisions were repeatedly used to persecute 
individuals, to prevent the establishment of lesbian and gay organisations, clubs, magazines or meeting places (Human Rights Watch, 1998: 55-62) and were only finally repealed in 2002 (Stychin, 2003) yet were interpreted in the UK cases as simple decriminalisation laws providing formal equality.

In one extraordinary case in 1999, an Adjudicator accepted Clause 1 of the Romanian Code but characterised Clause 5 as excessive, contrasting it with the 'sensible and moderate' Clause 28 then in force in Britain:

In contrast to the sensible and moderate legislation in force here [in the UK], merely preventing such proselytization amongst persons of an impressionable age, the Romanian Code clearly goes beyond a legitimate protection of young persons and public order, and intrudes in the private life of grown-ups. Why the Romanian authorities should have such a preoccupation with a perversion as harmless as it is unappealing to the vast majority of the population, I have no idea. (Beteringhe (1999).

Although such open acknowledgement of the resonances between the two countries anti-propaganda provisions is unusual, I suggest that the presence of Clause 28 has been influential, whether consciously or otherwise, in British refugee decisions. Clause 28 provided that:

A local authority shall not (a) intentionally promote homosexuality or publish material with the intention of promoting homosexuality; (b) promote the teaching in any maintained school of the acceptability of homosexuality as a pretended family relationship.

Clause 28 was passed during the Thatcher era in a climate of moral panic over the presence of gay-positive material in schools; much rhetoric around the Bill focused upon conversion of youngsters (Cooper, 1994: 126-145; J effrey-Poulter, 1991: 206211, 218-241; Rayside 1998: 19-43; Watney 1991: 387-401; and, Anna Marie Smith argues, intertwined with the contagion metaphor of AIDS: Smith, 1994: 183-239). Although there were no prosecutions under the Section (apart from an aborted attempt under the Scottish equivalent in 2000: Waites, 2001) the effect of the law was to intimidate schools on issues such as sex education, and to prevent local authorities from funding lesbian and gay community projects and events (Moran, 2001). Clause 28 was subject to sustained critique (see eg Cooper, 1994; Stychin, 1995: 38-54; Kaufmann and Lincoln 1991) and widely denounced; yet it remained law in the UK from 1988 until its eventual, and bitterly contested, (Waites, 2001; Moran, 2001; Wise, 2000) repeal in 2003. J effrey Weeks argued that the intent of Clause 28 
was to force Britain back into a narrow space of conformity in accordance with the 1967 Act (Weeks, 1989: 295). Much of the public discourse, both in passing the Clause and in opposing its repeal, was focused upon public space and upon the seductive powers of homosexual proselytization and corruption of youth. For supporters of the Clause (including the adjudicator in Beteringhe (1999)), speaking is seducing. In such a context it is difficult, if not impossible, for British decisionmakers to see the prevention of such speech elsewhere as persecutory under the Refugees Convention.

It is noteworthy that despite the lengthy and bitterly contested reform process in Britain leading to decriminalisation, an equal age of consent and the repeal of Clause 28 , it remains extremely commonplace for decision-makers to refer to the absence of criminal prohibition in sending countries as a basis - sometimes the only basis - for a finding that the country in question is a safe, tolerant non-persecutory environment (see eg Lepoev (2000); Svilpa (1999); Marapira (2001). The British Courts have not been mindful of the fact that decriminalisation in countries such as Russia, Lithuania, Romania, Bulgaria, Armenia and Estonia has been at the insistence of the Council of Europe, which required such steps before considering new member states (see eg Human Rights Watch, 1998: 30-38; Council of Europe, 2000; Stychin 2003). In these instances legal changes ought not necessarily be taken to reflect any kind of internal or organic change in the views of the community or authorities. Indeed some reforms have been undertaken with extreme reluctance by domestic authorities and debate around such reforms has led to increased vilification of lesbians and gay men and a discourse of homosexuality as 'imported' foreign depravity (see eg Human Rights Watch, 1998: 30-38).

\section{Law's violence}

These refugee determinations offer the prospect of uncomfortable commonalities in the sending and receiving countries. On occasion this is exposed through awkward comparisons, such as those involving Clause 28 or prohibitions on public sexual expression: 'we' do that too, so it must be lawful. Law exculpates law, and in doing so exposes its own violent impulses. 
In the 2001 case of Ashley, a gay man from Zimbabwe had been involved in a dispute with his male partner resulting in domestic violence. The police had been called and when questioned the couple had (in the words of the IAT) 'volunteered the carnal nature of their relationship' (Ashley (2001): para 2). The couple were charged with sodomy and after pleading guilty a 40 day suspended sentence and a fine was imposed. The applicant claimed that the court case had been reported in the newspaper and that as a result he was beaten up in a local bar by men who identified him from the report. In a recent report into homophobic violence in Southern Africa, Human Rights Watch and the International Gay and Lesbian Human Rights Commission found that front page newspaper reporting of criminal prosecutions for sodomy with full names of the defendants was common practice in Zimbabwe (Human Rights Watch, 1998: 88, 92). Yet the Tribunal held, apparently on the basis of supposition that,

Their pleas and remand...were reported in the local press in neutral terms: we are prepared to assume that the law in force in Zimbabwe required that, as would be the case here while proceedings were pending. (Ashley (2001): para 2).

While the Tribunal hesitatingly accepted that the appellant was beaten up in a bar by people who had somehow identified him as one of the subjects of the court case' (Ashley (2001): para 2, emphasis added) it held that neither the criminal law nor the police conduct was persecutory and there was

nothing to show that the appellant would have anything to fear as consensual sodomy in private (and the appellant has not claimed to have indulged in any other kind) is likely to remain undetected, as his and W's did till they chose to reveal it to the police (Ashley (2001): para 5).

It is strongly arguable that the case was wrongly decided, as there was no consideration at any level of the question of failure of police protection. ${ }^{x}$ Ashley's claim on police assistance in a situation of violence led to police initiated prosecution against him, which then led the applicant to fear the police and not approach them when subject to later violent assault. But more broadly the case is extraordinarily revealing of homophobic views on the Tribunal. In the Tribunal's view the harm was self inflicted; it twice stressed that Ashley 'chose' to 'volunteer' his relationship and did not consider that in future, even absent further prosecution, Ashley's ability to seek police protection for homophobic violence (or indeed for any other matter that could lead to a revelation of his sexuality) was severely limited. 
Ashley's case exemplifies law's violence at work, both in the sending and receiving countries. It demonstrates the crucial links between judicial and extra-judicial persecution in a country such as Zimbabwe where criminal sanctions are coupled with widespread social opprobrium. The judicial system initiated the harm through arrest and prosecution and then perpetuated it through publicising details of the case. Further harm to the applicant was surely the intended result of publishing such details. The press in Zimbabwe is state controlled and deeply implicated in the rising tide of vilification of gay men and lesbians since the mid 1990s (Human Rights Watch, 1998: 22-24) - but the agents of such harm become men in a bar or men on the street. The judicial system thus displaces and disclaims it own violence.

The receiving country also perpetuates the violence by disclaiming and disqualifying it. Decision-makers, even when not actually disbelieving it, invalidate the experience of violence. A suspended sentence and fine ('no more than $£ 5$ at the rate prevailing even then' - Ashley (2001): para 2) is not so bad, and certainly not persecution. The violence is declared invalid within this legal terrain because there is no state nexus: the bashing in the bar had nothing to do with the state that set it in motion, and the failure to seek police protection had nothing to do with the state whose officers initiated the original arrest. The victim is blamed as the author of his own misfortunes, and then taunted as to his abstemious future:

Unlike Messrs. Norris and Modinos [claimants who successfully argued that criminalisation of gay sex infringed their rights to private life in the ECHR, discussed above] who were practising homosexuals in their home countries, this appellant has expressed the intention of remaining faithful to W, who in turn has expressed the intention of staying in this country for as long as he can. In these circumstances, we see no real risk of any actual infringement of this appellant's right to private life, by being returned to a country which forbids the practices in which he says he wishes to indulge only with a person who will not be there. (Ashley (2001): para 8) ${ }^{x i}$

The facts of Ashley's case are very similar to a number of case studies in Romania prior to the 2002 reforms. In their 1998 report Human Rights Watch and the IGLHRC noted numerous instances where a gay man or couple came accidentally to the attention of the police, who pursued them in an aggressive manner (often 
subjecting them to physical and sexual assault), questioned them to elicit the names of other partners or known homosexuals, subjected them to invasive medical examinations, and publicised the details of their cases including names and sometimes photographs (Human Rights Watch, 1998: 18-29, 47-54).

Excepting the regularity of sexual assault by police, these accounts uncannily echo the techniques of policing in Britain prior to the Wolfenden reforms. Leslie Moran notes that the Wolfenden Committee studied sample convictions for private consensual gay sex and found that most of them had come into the legal process as a result of police investigations into an unrelated offence. Moran quotes at length the testimony of one such man who admitted to being homosexual after the police had raided his flat on a larceny inquiry and been 'extremely curious' about the single bedroom (Moran, 1996: 121-124). The man and his partner were repeatedly questioned, had their bed sheets removed for forensic testing, were forced to undergo medical examinations and were released only on the condition that they would live apart. Moran explores this testimony as an instance of a 'production moment' by which police transformed an invisible couple into a process of examination and a specific object for the law: homosexuality. It is also an exemplar of police inquiry being driven by animosity which is unfettered, indeed given scope and institutional power, by 'rarely enforced' criminal legislation. There was no legal imperative for the police in England in the 1950s to arrest two men because they had moisturiser and body building magazines in their bedroom, just as in Ashely's case there was no necessity for police in Zimbabwe to arrest both parties to a domestic dispute. The police arrested, questioned, examined and charged the men because they wanted to hurt them, and the law gave licence to that desire.

\section{Conclusion}

Refugee decision-makers, inexperienced in claims by sexual outsiders, fall back on their own understandings of the proper place of the sexual subject. In Britain this implicit conception of proper place has been deeply influenced by a specific normative construction of 'the private': that developed by the Wolfenden Committee as the solution, the only solution, to the 'problem' of homosexuality. This construction of the private, one that slips between both the normative and the spatial, 
is manifestly disadvantageous to lesbian and gay asylum seekers in Britain. It has informed an expectation of invisibility for sexual others, such that refugee decisionmakers have refused to credit applicants with the right to be open about their sexuality. This has led to holding or expecting that applicants be 'discreet' in their home countries to avoid persecution. Decision-makers have also manifestly failed to appreciate how repression and fear of persecution might contribute to such 'discretion', which is frequently assumed as a natural state.

The Wolfenden schema has also, perversely, contributed to a reluctance among British decision-makers to date to construe criminal penalties for gay sex as persecutory. Wolfenden provided a defence to the criminality of gay sex (if it was private, consensual, adult) and in doing so reaffirmed both the inherent wrongness of gay sex and the criminality of all other acts that fell outside the ambit of the defence. Any expression of sexual identity falling outside of this narrow realm of defensible homosexuality is still viewed as properly punishable by British authorities. This provides almost insurmountable barriers for asylum applicants, whose range of sexual expression must necessarily be public in order to have come to the attention of the agents of persecution.

At times awkward commonalities arise between the sending and receiving country, such as those between Romania's anti-proselytization provisions and Britain's own Clause 28, or between Britain's pre-1967 policing practices and those of Zimbabwean police in recent times. These parallels should not be ignored even though they occurred in the past. Although legal provisions such as Clause 28 in Britain have now been repealed, the refugee decisions examined betray the same underlying impulse: the homosexual must be disappeared. The violence of law in the site of British refugee claims is stark, as the victimisation of refugee claimants is erased and law exonerates law.

\section{REFERENCES}

David Bell (1995) 'Perverse Dynamics, Sexual Citizenship and the Transformation of Intimacy' pp 304-317 in David Bell and Gill Valentine (eds) Mapping Desire: Geographies of Sexualities. London: Routledge. 
Charles Blake (2001) Judging Asylum and Immigration Claims: The Human Rights Act and the Refugee Convention' Public Money and Management J uly-September: 25-28.

Davina Cooper (1994) Sexing the City: Lesbian and Gay Politics Within the Activist State. London: Rivers Oram.

Davina Cooper (2001) 'Like Counting Stars?: Re-Structuring Equality and the SocioLegal Space of Same-Sex Marriage', pp 75-96 in Robert Wintemute and Mads Andenæes (eds) Legal Recognition of Same-Sex Partnerships: A Study of National, European and International Law. Oxford: Hart.

Mary Crock (2002) The Refugees Convention at 50: Mid-Life Crisis or Terminal Inadequacy? An Australian Perspective' pp 47-90 in Susan Kneebone (ed) The Refugees Convention 50 Years On. Aldershot: Ashgate.

Council of Europe (2000) Armenia, Application for Membership of the Council of Europe, Report 2000 para 34 http:// assembly.coe.int/ Documents/WorkingDocs/ doc00/ EDOC8756.HTM

Council of the European Union (2003) Proposal For A Council Directive On Minimum Standards For The Qualification And Treatment Of Third Country Nationals And Stateless Persons As Refugees Or As Persons Who Otherwise Need International Protection, 6733/ 03, 2001/0207 (CNS), Brussels 28 February 2003.

Catherine Dauvergne and J enni Millbank (2003) 'Before the High Court: Applicants S396/ 2002 and S395/2002, a Gay Refugee Couple from Bangladesh' Sydney Law Review 25: 97-124.

Roz Germov and Francesco Motta (2003) Refugee Law in Australia. Melbourne: Oxford University Press.

Rodger Haines (2003) 'Gender Related Persecution', pp319-350 in Erika Feller, Volker Turk and Frances Nicholson (eds) Refugee Protection in International Law: UNHCR's Global Consultations on International Protection. Cambridge: Cambridge University Press.

Emma Henderson (1996) ‘Of Signifiers and Sodomy: Privacy, Public Morality and Sex in the Decriminalisation Debates' Melbourne University Law Review 20: 1023-1047.

Human Rights Watch/International Gay and Lesbian Human Rights Commission (1998) Public Scandals: Sexual Orientation and Criminal Law in Romania. New York: HRW/ IGLHRC.

Human Rights Watch/International Gay and Lesbian Human Rights Commission (2003) More than a Name: State-sponsored Homophobia and Its Consequences in Southern Africa. New York: HRW. Available at http:// www.hrw.org/ reports/2003/ safrica/ safriglhrc0303.pdf.

Stephen J effery-Poulter (1991) Peers, Queers and Commons: The Struggle for Gay Law Reform from 1950 to the Present. London: Routledge. 
Susan Kneebone (2002) 'Natural J ustice and Non-Citizens: A Matter of Integrity?'

Melbourne University Law Review 26: 355-380.

Helene Lambert (1995) Seeking Asylum: Comparative Law and Practice in Selected European Countries. Dordrecht: Martinus Nijoff.

The Law Society (UK) (2003) Early Access to Good Quality Legal Advice: Written Submission to the Select Committee on Home Affairs. Appears in Home Office (2003) First Report: Asylum and Immigration (Treatment of Claimants etc) Bill, Report \# HC 109; available at http:/ / www.parliament.the-stationeryoffice.co.uk/ pa/ cm200304/cmselect/ cmhaff/ 109/10902.htm.

Gail Mason (2002) The Spectacle of Violence: Homophobia, Gender, and Knowledge. New York: Routledge.

Derek McGhee (2000) 'Accessing Homosexuality: Truth, Evidence and the Legal Practises for Determining Refugee Status - The Case of Ioan Vraciu' 6 Body and Society 29-50.

Derek McGhee (2001) 'Persecution and Social Group Status' J ournal of Refugee Studies 14: 20-42.

Penelope Mathew (2002) 'Safe For Whom? The Third Country Concept Finds a Home in Australia' pp 133-172 in Susan Kneebone (ed) The Refugees Convention 50 Years On. Aldershot: Ashgate.

J enni Millbank (1995) 'Fear of Persecution or Just a Queer Feeling? Refugee Status and Sexual Orientation in Australia' Alternative Law J ournal 20: 261-265.

J enni Millbank (2002) 'Imagining Otherness: Refugee Claims on the Basis of Sexuality in Canada and Australia' Melbourne University Law Review 26: 144-177.

Jenni Millbank (2003) 'Gender, Sex and Visibility in Refugee Claims on the Basis of Sexual Orientation' Georgetown Immigration Law J ournal 18: 71-110.

J oe Moran (2001) 'Childhood Sexuality and Education: The Case of Section 28' Sexualities 4: 73-89.

Leslie Moran (1996) The Homosexual(ity) of Law. London: Routledge.

Wayne Morgan (1994) 'Identifying Evil for What it is: Tasmania, Sexual Perversity and the United Nations' Melbourne University Law Review 19: 740-757.

Wayne Morgan (2000) 'Queering International Human Rights Law', pp 208-225 in Carl Stychin and Didi Herman (eds) Sexuality in the Legal Arena. London: Athlone.

Wayne Morgan, Dianne Otto; Kristen Walker (1995) 'Rejecting (in)tolerance: Critical Perspectives on the United Nations Year for Tolerance' Melbourne University Law Review 20: 190-217.

Anna Marie Smith (1994) New Right Discourses on Race and Sexuality: Britain 1968-1990. Cambridge: Cambridge University Press. 
David Rayside (1998) On the Fringe: Gays and Lesbians in Politics. Cornell: Cornell University Press.

Carl Stychin (1995) Law’s Desires: Sexuality and the Limits of J ustice. London: Routledge.

Carl Stychin (1998) A Nation By Rights. Philadelphia: Temple.

Carl Stychin, (2000) '“A Stranger to its Laws": Sovereign Bodies, Global Sexualities, and Transnational Citizens' J ournal of Law and Society 27: 601-25.

Carl Stychin, (2003) Governing Sexuality. Oxford: Hart.

Mark Symes (2000) Caselaw on the Refugee Convention: The United Kingdom's Interpretation in Light of the International Authorities. London: Refugee Legal Centre.

Robert Thomas (2003) 'Asylum Appeals Overhauled Again' Public Law Summer: 260-271

Patricia Tuitt (1996) False Images: The Law's Construction of the Refugee. London: Pluto.

UNHCR (2001) Protecting Refugees: Questions and Answers, www.unhcr.ch.

UNHCR, UNHCR Handbook on Procedures and Criteria for Determining Refugee Status under the 1951 Convention and the 1967 Protocol Relating to the Status of Refugees (1992). Available at http:/ / www.unhcr.ch/ cgibin/texis/vtx/home/ +5wwBm el4VpwwwwnwwwwwwwmFqhT0yfEhFqhT0yfEtFqn p1xcAFqhT0yfEcFqorwDmxdd̄ADzmxwwwwwww1FqmRbZ/ opendoc.pdf.

UNHCR, (2002) Guidelines on International Protection: Gender-Related Persecution within the context of Article 1A(2) of the 1951 Convention and/ or its 1967 Protocol relating to the Status of Refugees, HRC/GIP/ 02/ 01.

Kristen Walker (2000) 'Sexuality and Refugee Status in Australia' International J ournal of Refugee Law 12: 175-211.

Matthew Waites (2003) 'Equality at Last? Homosexuality, Heterosexuality and the Age of Consent in the United Kingdom' Sociology 37: 637-655.

Matthew Waites (2001) 'Regulation of Sexuality: Age of Consent, Section 28 and Sex Education' Parliamentary Affairs 54: 495-508.

Simon Watney (1991) 'School's Out', pp 387-401 in Diana Fuss (ed) Inside/ Out: Lesbian Theories, Gay Theories. New York: Routledge.

J effery Weeks (1977) Coming Out: Homosexual Politics in Britain, from the Nineteenth Century to the Present. London: Quartet.

J effery Weeks (1989) Sex, Politics and Society: The Regulation of Sexuality Since 1800, 2nd ed. London: Longman. 
Sue Wise (2000) “New Right” or "Backlash"? Section 28, Moral Panic and

"Promoting Homosexuality"' Sociological Research Online 5(1): available online at http:// www.socresonline.org.uk/5/1/ wise.html.

\begin{abstract}
AUSTRALIAN CASES
Appellant S395/ 2002 v Minister for Immigration and Multicultural Affairs (2003) 203 ALR 112

MMM v Minister for Immigration \& Multicultural Affairs [1998] 1664 FCA
\end{abstract}

\title{
UK Refugee CASES
}

Apostolov v SSHD (Unreported, IAT No 18547, 24 September 1998) ('Apostolov'). Available from EIN database, http:// www.ein.org.uk

Aslani v SSHD [2002] (Unreported, IAT No HX-18924-2001, 24 J anuary 2002)

('Aslani'). Available from EIN database, http:// www.ein.org.uk

R v Immigration Appeals Tribunal ex parte Arku (Unreported, UK High Court, Queen's Bench Division, McCullough J , 31 October 1997) ('Arku')

R v Secretary of State for the Home Department ex parte Arku (Unreported, UK High Court, Queen's Bench Division, Hirst LJ , 19 December 1997)

Ashley v SSHD [2001] (Unreported, IAT No 01THO1837, 17 August 2001) ('Ashley'). Available from EIN database, http:// www.ein.org.uk

R v SSHD ex parte Bell [2000] Imm AR 396 ('Bell')

Beteringhe v SSHD [1999] (Unreported, IAT No HX/ 707917, 11 October 1999)

('Beteringhe'). Available from EIN database, http:// www.ein.org.uk

Dumitru v SSHD [2000] (Unreported, IAT No HX-79282-95, 3 April 2000)

('Dumitru'). Available from EIN database, http:// www.ein.org.uk

Hadivoa v SSHD [2003] EWCA Civ 701.

Jain v SSHD [1999] EWJ No 5243.

R v SSHD ex parte Khan (Unreported, UK High Court, Queen's Bench Division, Collins J , 17 May 1999) ('Khan')

Kizza v SSHD [2002] UKIAT06100, 15J anuary 2003

Lupsa v Immigration Appeal Tribunal [1999] EWJ No 4288 ('Lupsa')

Maingi v SSHD [2001] (Unreported, IAT No HX-59173-00, 3 May 2001). Available from EIN database, http:// www.ein.org.uk 
Musavi v SSHD [2002] (Unreported, IAT No HX05135-2002, 30 August 2002).

Available from EIN database, http:// www.ein.org.uk

Nazari v SSHD [2002] (Unreported, IAT No HX-57726-2001, 11 November 2002)

('Nazari'). Available from EIN database, http:// www.ein.org.uk

R v SSHD ex parte Binbasi [1989] Imm AR 595 ('Binbasi')

R v SSHD ex parte Lepoev [2000] EWJ No1319 ('Lepoev')

R (on the application of Mbasvi) v Immigration Appeal Tribunal [2001] EWHC

Admin 891

R (on the application of S) v SSHD [2003] EWHC 352 (Admin) ('S')

Ramirez-Rojas v SSHD [2000] (Unreported, IAT No HX-81245-96, 10 April 2000)

('Ramirez-Rojas'). Available from EIN database, http:// www.ein.org.uk

Saeed v SSHD [2002] UKIAT 01465 ('Saeed'). Available from EIN database,

http:// www.ein.org.uk

Sankale v SSHD [2001] (Unreported, IAT No HX-14649-2001, 3 December 2001).

Available from EIN database, http:// www.ein.org.uk

Sealeunu v SSHD [1997] EWJ No 186

Secretary of State for the Home Department v Z; A v Secretary of State for the Home Department; Mv Secretary of State for the Home Department [2002] EWCA Civ 952 ('Z, A and M")

Sever v SSHD [2002] (Unreported, IAT No HX51619-2001, 6 December 2002). Available from EIN database, http:// www.ein.org.uk

R v Immigration Appeal Tribunal ex parte Shah and Islam v Secretary of State for the Home Department [1999] 2 AC 629; [1999] 2 All ER 545; [1999] 2 WLR 1015; [1999] Imm AR 283 ('Shah and Islam')

Svilpa v IAT [1999] EWJ No 6959

T v Special Immigration Adjudicator [2000] EWJ No 3020 ('T')

R (Ex parte Ullah) v Special Adjudicator; Do v Secretary of State for the Home Department [2004] UKHL 26; [2003] 3 All ER 1174; [2002] EWCA Civ 1856 ('Ullah and Do').

Vraciu v SSHD (Unreported, IAT No 11559, 21 November 1994). Available from EIN database, http:// www.ein.org.uk

\section{Other UK Cases}

Knuller v Director of Public Prosecutions [1973] AC 435 


\title{
Masterson v Holden [1986] 3 All ER 39
}

Parkin v Norman, Valentinev Lilley [1982] 2 All ER 583

R v Batten [1990] The Times, 27 February 1990

R v Gibson [1991] 93 CR App R 9

Rv Knuller [1972] QB 179; [1971] 3 All ER 314

R v Lemon, Rv Gay News Ltd [1979] AC 617; [1979] 1All ER 898; [1979] 2 WLR 281

R v Mattison [1990] Crim LR 117

X v Y [2003] (Unreported, Employment Appeal Tribunal No EAT/ 0765/ 02/TM, 11

June 2003)

\section{European Court of Human Rights Cases}

\author{
ADT v UK [2000] ECHR 35765/97 \\ Dudgeon v United Kingdom (1982) 4 EHRR 149; [1981] ECHR 7525/ 76 \\ Modinos v Cyprus [1993] 16 EHRR 485 \\ Norris v Ireland (1991) 13 EHRR 186
}

\begin{abstract}
- Senior Lecturer in Law, University of Sydney. This paper is based on research devised and undertaken with Catherine Dauvergne, Canada Chair in Migration Law, University of British Columbia and supported by grants from the University of Sydney Faculty of Law Legal Scholarship Support Fund. Thanks to Tiffany Hambley for her invaluable research assistance on the project.
\end{abstract}

\begin{abstract}
${ }^{i}$ The legal definition of a refugee is drawn from the refugee convention and adopted into domestic law of the receiving nations. Article $1 \mathrm{~A}(2)$ of the Convention defines a refugee as any person who: '...owing to wellfounded fear of being persecuted for reasons of race, religion, nationality, membership of a particular social group or political opinion, is outside the country of his nationality and is unable or, owing to such fear, is unwilling to avail himself of the protection of that country; or who, not having a nationality and being outside the country of his former habitual residence, is unable or, owing to such fear, is unwilling to return to it. 1951 Convention Relating to the Status of Refugees 189 UNTS 150, as amended by the 1967 Protocol Relating to the Status of Refugees 606 UNTS 267. For an overview of the social group category and sexuality in the UK, Canada, USA, New Zealand and Australia, see Walker, 2000.

ii I do not claim any universalised experience of sexual identity. Yet applicants are united in that their same-sex attractions and relationships have meant that they were subject to violence or to the real possibility of violence; so their experience of sexuality, however articulated, has had real material consequences. I use lesbian and gay as convenient shorthand, and as a political organizing principle, knowing full well that these terms are not necessarily meaningful in non-Western cultures.

iii See Millbank, 2002; 2003. As at December 2002, the average success rates of claims in our study were: UK 21.8\%; Australia 22.03\%; Canada 48.9\%. However note that unlike Canada and Australia where the Tribunal either grants or denies refugee status, the UK Tribunal has the option of returning the matter to an adjudicator to re-decide. The majority of the 'positive' UK decisions in our study were in fact remittals, and so may not have resulted in a grant of refugee status.
\end{abstract}

iv Although Wolfenden was principally concerned with male homosexuality (as only one offence covered lesbian sex), and the 1967 reforms that followed were exclusively so, they have nonetheless had a major impact upon 
'the lesbian of law'. Although the cultural and legal forces at work are not identical to the construction of male homosexuality, lesbians too face the imperative to be 'disappeared' due to their non-conforming sexuality. In some ways this expectation is heightened due to pre-existing cultural expectations that women's sexuality in general ought to be passive and invisible (Millbank, 2002). So, while not intending to treat lesbians as identical to gay men (or as a gendered subset of 'homosexual') and while acknowledging that in many instances lesbians and gay men may not even be similarly situated, I do contend that the Wolfenden schema of privacy has had a profound effect on lesbians as well as gay men.

${ }^{v}$ The Asylum and Immigration Bill (2003) currently before Parliament seeks to restrict this limited review even further, promising to replace the current two-tier system with a single-tier of non-reviewable decision-making. The Bill would also preclude any judicial review of asylum decisions.

${ }^{\mathrm{vi}}$ See eg: Lepoev (2000) para 12; Sealeunu (1997): para 17.

vii See eg Parkin v Norman, Valentine v Lilley (1982); $R$ v Batten (1990); $R v$ Mattison (1989); $R v$ Gibson (1991); X $\vee Y$ (2003).

viii Decisions at Tribunal level in Australia were initially divided, but by 1998 the Federal Court of Australia held that criminal laws which target 'homosexual acts' either specifically or by selective application, if enforced, may be regarded as persecutory (MMM (1998): 6). This was affirmed in obiter by the majority of the High Court in 2003 (S395).

${ }^{\text {ix }}$ Note that the IAT held that such prosecution would be persecution: para 13.

${ }^{\mathrm{x}}$ This claim was remitted for reconsideration on the issue of A's Art 8 rights. Note that this would not now occur under Ullah.

${ }^{x i}$ The Court held that the lack of consideration of his Art 8 Convention rights were in error and remitted the case for reconsideration. Under Ullah this is no longer required and so the claim cannot succeed. 